\title{
PEMANFATAAN BIJI KARET SEBAGAI BAHAN PEMBUATAN PUPUK ORGANIK CAIR DI KUD KARYA MUKTI KECAMATAN JUJUHAN ILIR KABUPATEN BUNGO
}

\section{UTILIZATION OF RUBBER SEED AS A MATERIAL FOR MAKING LIQUID ORGANIC FERTILIZER IN KUD KARYA MUKTI JUJUHAN ILIR DISTRICT BUNGO REGENCY}

\author{
Diah Riski Gusti ${ }^{1)}$, Edwin Permana ${ }^{2)}$, Ratih Dyah Puspitasari ${ }^{3)}$, Indra Lasmana \\ $\left.\operatorname{Tarigan}^{4}\right) *$ \\ ${ }^{1)}$ Fakultas Sains dan Teknologi, Universitas Jambi. email: diah@unja.ac.id \\ ${ }^{2)}$ Fakultas Sains dan Teknologi, Universitas Jambi. email: edwinpermana@unja.ac.id \\ ${ }^{3)}$ Fakultas Sains dan Teknologi, Universitas Jambi. email: ratihdyah@unja.ac.id \\ ${ }^{4)}$ Fakultas Sains dan Teknologi, Universitas Jambi. email: indratarigan@unja.ac.id
}

\begin{abstract}
ABSTRAK
Provinsi Jambi memiliki peran yang cukup besar dalam dalam bidang perkebunan karena memiliki beberapa komoditi unggulan seperti perkebunan kelapa sawit dan karet. Kabupaten Bungo tahun pada tahun 2016 memiliki perkebunan karet seluas 98220 hektar dan perkebunan kelapa sawit mencapai 97.630 Ha. Penggunaan tanah secara simultan dalam perkebunan sawit akan mengurangi kualitas tanah, sehingga berdampak pada kualitas sawit yang dihasilkan. Untuk meningkatkan produksi, digunakan pupuk, yang biasanya digunakan berupa pupuk sintesis, yang dalam jangka panjang akan memberikan dampak negatif bagi lingkungan dan tanah, sehingga dibutuhkan keterampilan masyarakat dalam menghasilkan pupuk berbasis alam (organik) dengan memanfaatkan limbah hasil pertanian. Salah satu limbah pertanian yang dilaporkan oleh Koperasi Unit Desa (KUD) Karya Mukti Kecamatan Jujuhan Ilir, Kabupaten Bungo adalah biji karet, yang hampir sebagian besar belum termanfaatkan dengan baik. Biji karet diketahui memiliki mikroorganisme lokal yang bersifat probiotik sebagai fermenter dalam reaksi fermentasi menghasilkan pupuk organik. Pengabdian kepada masyarakat dalam mengolah potensi tersebut sangat diperlukan dalam rangka penerapan teknologi tepat guna bagi petani dan untuk menerapkan sistem pertanian organik untuk menciptakan produk pertanian yang berkualitas dan sehat serta menciptakan salah satu pupuk organik cair yang ramah lingkungan. Tujuan Program ini adalah untuk memberikan pelatihan dan kompetensi kepada masyarakat dalam mengolah limbah perkebunan untuk menghasilkan pupuk organik cair yang merupakan salah satu dekomposer yang dapat digunakan untuk meningkatkan kualitas hasil perkebunan. Selain itu, untuk jangka panjang, diharapkan program ini dapat meningkatkan keterampilan masyarakat untuk menghasilkan produk yang berkualitas dan berdaya saing.
\end{abstract}

Kata kunci: Sawit, Karet, Fermenter, Pupuk Cair

\section{ABSTRACT}

Jambi Province has a significant role in the plantation sector because it has several superior commodities such as oil palm and rubber plantations. In 2016, Bungo District had rubber plantations covering 98.220 hectares and oil palm plantations 97.630 hectares. The simultaneous use of land in oil palm plantations will reduce the quality of the soil, thus having an impact on the quality of the palms produced. Usually, synthetic fertilizers use to increase production yields. The continued use of synthetic fertilizers will harm the soil and the environment, so that community skills are needed to produce natural-based (organic) fertilizers by utilizing agricultural waste. The Karya Mukti cooperative reports that rubber seeds are agriculture waste that has not to use appropriately. Rubber seeds are known to have local microorganisms that are probiotic as a fermenter in the fermentation reaction to produce organic fertilizer. Community service in processing this potential is needed to apply appropriate technology for farmers and to apply an organic farming system to create quality and healthy agricultural products and to create one of the environmentally friendly liquid 
organic fertilizers. This program aims to provide training and competence to the community in processing plantation waste to produce liquid organic fertilizer, which uses the decomposer to improve the quality of plantation products and also improve community skills to make quality and competitive products.

Keywords: Palm Oil, Rubber, Fermenter, Liquid fertilizer

\section{PENDAHULUAN}

Provinsi jambi merupakan salah satu provinsi di Pulau Sumatera yang memiliki peran yang cukup besar dalam menghasilkan beberapa komoditas unggulan hasil pertanian dan perkebunan seperti kelapa sawit, perkebunan karet, perkebunan lada yang secara langsung dapat meningkatkan pertumbuhan ekonomi daerah serta mampu memberikan sumbangan terhadap pendapatan Daerah Regional Bruto (PDRB). Berdasarkan data BPS Kabupaten Bungo tahun 2016, perkebunan karet di Kabupaten Bungo seluas 98220 hektar. Kabupaten Bungo juga merupakan salah satu sentral perkebunan tanaman kelapa sawit yang ada di provinsi Jambi. Luas perkebunan kelapa sawit rakyat untuk komoditas kelapa sawit mencapai 97.630 ha dengan produksi mencapai 188.534 ton dengan rata-rata penerimaan petani per Ha adalah 1.963.264 Rupiah/bulan.

Biji karet dari perkebunan karet oleh sebagian petani digunakan hanya sebagai bahan lemparan atau bahan yang dapat dipakai sebagai campur pakan ternak, namun disisi lain biji karet memiliki manfaat yang menguntungkan jika diolah dengan baik salah satunya sebagai pupuk organik mengingat luasnya perkebunan di kabupaten Bungo. KUD Karya Mukti Kecamatan Pelepat Ilir Kabupaten Bungo memiliki jumlah anggota koperasi 400 orang dengan memiliki jumlah pendapatan per tahun Rp.500.000.000,-. Jumlah Kelompok tani sawit sebanyak 24 kelompok tani dengan masing-masing luas lahan 2 ha per orang. Dengan jumlah lahan yang luas memungkinkan untuk memberdayakan petani dan anggota koperasi meningkatkan omset produksi untuk meningkatkan penghasilan.

Berdasarkan analisis situasi dan diskusi dengan Ketua KUD Karya Mukti diKecamatan Jujuhan Ilir Kabupaten Bungo sebagai mitra untuk kegiatan program pengabdian kepada masyarakat ini, dapat disimpulkan bahwa permasalahan yang dialami oleh mitra adalah: 1) banyaknya biji karet yang ada di Kecamatan Jujuhan Ilir yang dihasilkan, 2) dilokasi mitra biji karet yang tidak dimanfaatkan dan dibuang begitu saja, 3) dilokasi mitra belum pernah dilakukan kegiatan pelatihan/penyuluhan mengenai pembuatan pupuk organik cair, sehingga skill warga belum maksimal, 4) mitra kurang memahami dalam pemilihan pupuk dan perawatan tanaman yang baik, 5) sulitnya mitra dalam mendapatkan pupuk yang murah dan ramah lingkungan, 6) masih terdapatnya system teknologi pemupukan pada tanaman yang bersifat tradisional, 7) rendahnya produksi dan kualitas kelapa sawit sehingga memperolah hasil yang tidak efisien, 8) tingginya biaya produksi 
dikarenakan petani terlalu berlebihan dalam aplikasi penggunaan pupuk.

Berdasarkan dari permasalahan mitra, persoalan prioritas yang dialami mitra dan prioritas yang disepakati untuk diselesaikan berkaitan dengan rendahnya laju pertumbuhan tanaman kelapa sawit dan rendahnya produksi kelapa sawit yaitu dengan menerapkan teknologi penggunaan pupuk yang baik dan pemberian pupuk organik cair (mikroorganisme lokal) yang murah dan mudah didapat. Pemahaman terhadap perawatan yang baik sehingga bisa memangkas biaya produksi tanaman sawit. Mitra bisa membuat pupuk sendiri dari bahan alami yang mudah didapat.

Berdasarkan analisis situasi dan permasalahan mitra/warga diKecamatan Jujuhan Ilir Kabupaten Bungo, maka solusi yang ingin ditawarkan dari kegiatan program pengabdian kepada masyarakat (PPM) ini adalah: 1) Pelaksana program pengabdian kepada masyarakat akan memberikan Penyuluhan Pembuatan Pupuk Organik Cair, 2) Mengajak kepada warga masyarakat untuk bersama-sama pelaksana program pengabdian kepada masyarakat membuat Pupuk Organik Cair.

Target dilaksanakannya program pengabdian kepada masyarakat ini adalah mitra mampu: 1) menerapkan teknologi penggunaan pupuk yang baik dan pemberian pupuk organik cair yang murah dan mudah didapat. 2) Pemahaman terhadap perawatan yang baik sehingga bisa memangkas biaya produksi tanaman sawit 3) Mitra bisa membuat pupuk sendiri dari bahan alami yang mudah didapat.

\section{METODE PELAKSANAAN KEGIATAN}

Pelaksanaan program pengabdian kepada masyarakat ini akan dilaksanakan di Kecamatan Jujuhan Ilir Kabupaten Bungo. Waktu Pelaksanaannya diperkirakan pada bulan April - November 2020.

Kegiatan ini dilakukan dengan menggunakan metode pelatihan penerapan IPTEKS. Pelaksanaan kegiatan pengabdian masyarakat ini melalui tahapan sebagai berikut:

1. Melakukan survei untuk mengidentifikasi khalayak sasaran secara rinci, meliputi survei pemupukan, serta identifikasi kebutuhan mendasar petani KUD Karya Mukti

2. Melakukan kontrak perjanjian kerjasama antara petani KUD Karya Mukti dengan Tim

3. Melakukan pembentukan panitia kecil yang terdiri dari warga dan pihak pelaksana untuk mempermudah pelaksanaan program pengabdian kepada masyarakat.

4. Merencanakan tempat dilaksanakannya pelatihan, berikut waktu pelaksanaan, juga melakukan persiapan-persiapan yang dibutuhkan.

5. Pelaksanaan pelatihan. Pada kegiatan ini, peserta diminta untuk menyimak dengan seksama penjelasan mengenai pembuatan pupuk organik. Kemudian dilakukan diskusi secara bersama mengenai program yang ditawarkan. 
6. Tahap praktek pembuatan. Pada kegiatan ini peserta pelatihan diajak untuk mempraktekkan sendiri tentang Pupuk Organik cair.

7. Evaluasi dilakukan dalam 3 (tiga) tahapan, yaitu (1) mulai dari perencanaan, (2) selama proses pelaksanaan dan (3) akhir kegiatan. Evaluasi pada awal kegiatan dilakukan untuk memantapkan rencana kegiatan yang akan dilakukan. Evaluasi selama proses pelaksanaan dilakukan untuk mengetahui keterlaksanaan program dan umpan balik untuk perbaikan lanjutan. Evaluasi pada akhir kegiatan dilakukan untuk tingkat keberhasilan dari keseluruhan program kegiatan.

\section{Pembuatan Mikroorganisme Lokal (MOL)}

Mikroorganisme Lokal (MOL) adalah cairan hasil fermentasi yang mengandung mikroorganisme hasil produksi sendiri dari bahan alami yang tersedia di lingkungan kita. Bahan tersebut merupakan tempat yang cocok untuk hidup dan berkembangnya mikroorganisme yang berguna dalam mempercepat penghancuran bahan-bahan organik atau sebagai tambahan nutrisi bagi tanaman. Keunggulan penggunaan MOL yang paling utama adalah murah bahkan tanpa biaya, dengan memanfaatkan bahanbahan yang ada di sekitar (Palupi, 2015).

\section{Pembuatan Pupuk Organik Cair}

Biji karet yang ditumbuk menggunakan lesung bersama nanas kemudian dicampur dengan ragi. Masukkan ke wadah yang berisi air cucian beras. Setelah itu masukkan biji karet, nanas kedalam jerigen, kemudian masukkan air cucian beras yang telah ditambahkan ragi, lalu dimasukkan air kelapa dengan $0,5 \mathrm{~L} / \mathrm{kg}$ bahan baku dan diaduk sampai merata. Setelah MOL dimasukkan kedalam jerigen ditutup rapat. Tutup jerigen dilubangi tengahnya dan diberi selang. Ujung selang yang masuk ke dalam jerigen hanya sampai batas di atas bahan POC, sedangkan ujung selang lainnya dimasukkan ke dalam botol yang telah diberi $3 / 4$ air hingga sampai ke dalam air untuk menghilangkan gas. Dengan cara seperti ini jerigen tidak perlu di buka setiap hari. Lama fermentasi dilakukan selama 2 minggu hasil fermentasiberupa larutan POC.

\section{Peserta Program dan Pendampingan Program}

Peserta dalam kegiatan program pengabdian kepada masyarakat ini adalah petani yang terhimpun dalam KUD Karya Mukti. Pelaksanaan program mempersiapkan tempat dan peralatan yang dibutuhkan. Program kegiatan dilaksanakan dengan memberikan penyuluhan kepada masyarakat mengenai pembuatan pupuk organik cair dari biji karet, disertai praktik pembuatan pupuk cair oleh masyarakat didampingi tim pelaksana program. Hal ini bertujuan agar masyarakat selaku peserta program menjadi masyarakat yang mandiri dan produktif, sehingga mampu mendirikan industri rumahan (home industry) yang memiliki produk berkualitas dan berdaya saing.

\section{HASIL DAN PEMBAHASAN}

\section{Pembuatan pupuk organik cair}

Sebelum melaksanakan kegiatan penyuluhan dan pelatihan yang dilaksanakan, 
maka tim kegiatan pengabdian masyarakat melaksanakan pembuatan pupuk organik cair. Adapun tahap-tahap pembuatan pupuk sebagai berikut:

1. pemisahan cangkang biji karet

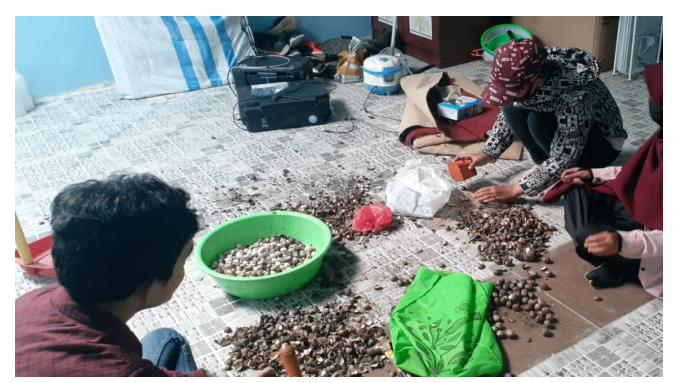

Gambar 1. Pemisahan cangkang biji karet

2. biji karet yang telah terpisah dari cangkang direndam dalam air dengan penambahan arang sekam padi dan air garam selama 30 menit, kemudian direbus dengan air selama kurang lebih 30 menit.

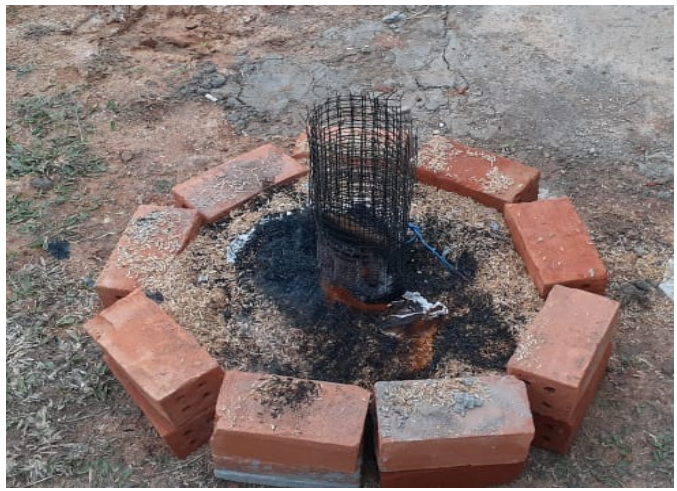

Gambar 2. Proses pembuatan arang sekam padi

3. biji karet yang telah direbus kemudian ditiriskan dan dikeringkan kembali

4. biji karet yang telah ditunkan kadar honnya ditumbuk menggunakan lesung bersama nanas

5. ragi dihaluskan lalu dimasukkan kedalam wadah yang berisi air cucian beras

6. setelah itu masukkan biji karet, nanas kedalam jerigen, kemudian masukkan air cucian beras yang telah ditambahkan ragi, lalu masukkan air kelapa dan diaduk sampai merata

7. tutup jerigen dilubangi tengahnya dan diberi selang. Ujung selang yang masuk ke dalam jerigen hanya sampai batas di atas bahan MOL, sedangkan ujung selang lainnya dimasukkan ke dalam botol yang telah diberi $3 / 4$ air hingga sampai ke dalam air untuk menghilangkan gas dan dilakukan fermentasi selama 2 minggu.

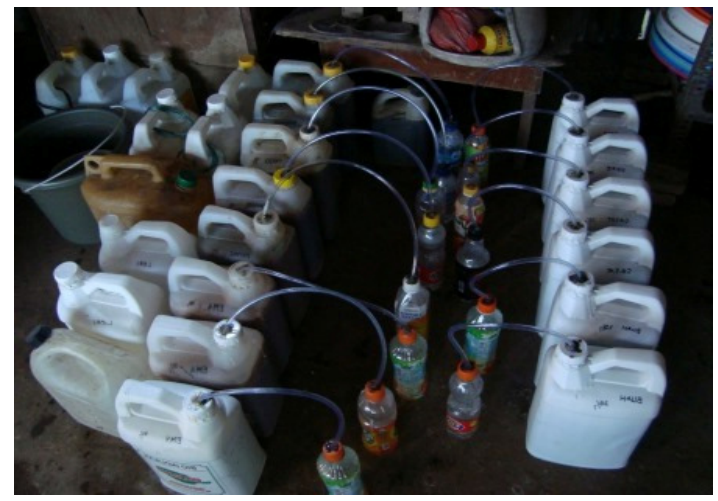

Gambar 3. Proses Fermentasi

Untuk mengetahui bahwa pupuk cair sudah jadi adalah dengan tidak terlihat gelembunggelembung pada cairan.

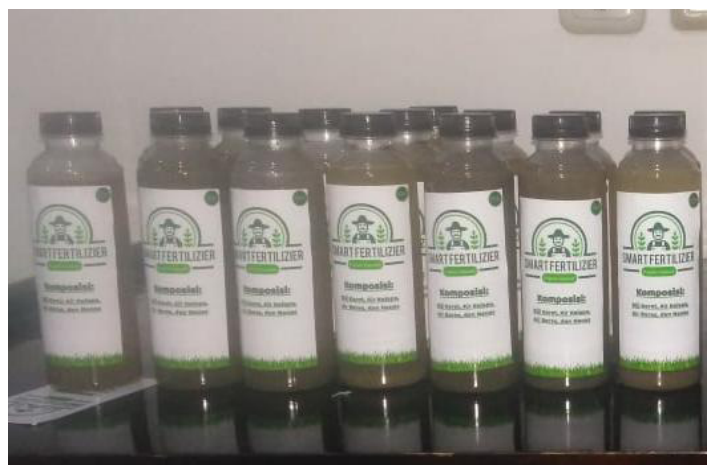

Gambar 4. Produk pupuk organik cair

\section{Pelaksanaan Kegiatan}

Kegiatan pengabdian masyarakat ini dilaksanakan pada tanggal 29 dan 30 Juli 2020. Adapun masyarakat yang hadir dalam pengabdian ini berjumlah sekitar 40 orang, terdiri dari kepala desa, ketua Koperasi Unit 
Desa, staf KUD, para petani dan masyarakat umumnya.

Pada saat pelaksanaan, masyarakat sangat antusias mengikuti kegiatan pengabdian masyarakat. Pertama kali kegiatan dibuka oleh kepala desa Bapak Iwan, Ketua KUD Bapak Riswanto, dan Bapak Edwin Permana, ST, MT sebagai perwakilan Universitas Jambi.

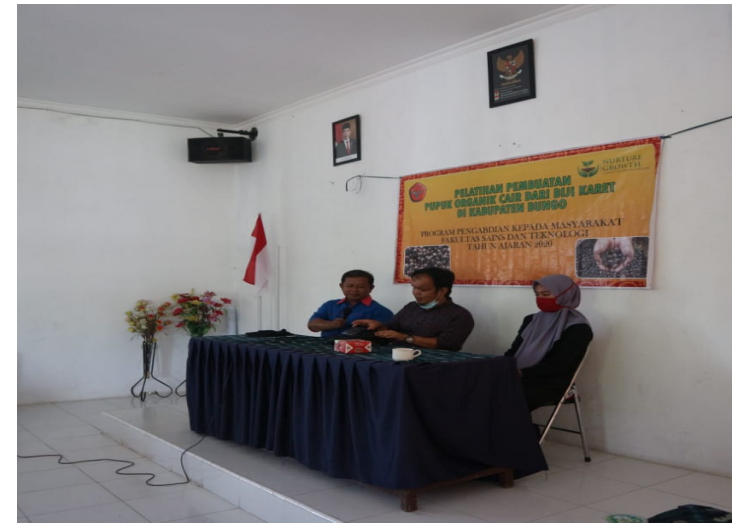

Gambar 5. Pembukaan kegiatan PPM

Pelaksanaan Kegiatan Pembuatan Pupuk Organik cair dibuat di dalam ruangan aula sesuai dengan prosedur kegiatan yang telah dirancang oleh tim pengabdian. Pelatihan pembuatan pupuk organik cair ini langsung dilakukan di depan masyarakat dan secara langsung mereka sangat interaktif bertanya pada saat pelatihan berlangsung.

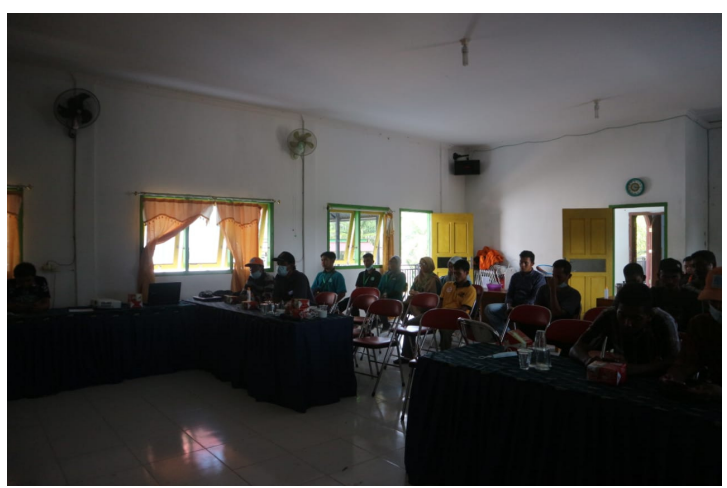

Gambar 6. Peserta mengikuti kegiatan dengan antusias

Kegiatan dilakukan dengan dua tahapan yaitu pada awal kegiatan disampaikan kepada masyarakat mengenai pemanfaatan biji karet sebagai bahan baku alternatif untuk pembuatan pupuk organik cair serta dasardasar pembuatan pupuk organik cair. Tahapan kegiatan yang kedua yaitu praktik pembuatan pupuk cair. Kegiatan ini dilakukan oleh peserta dari mitra yang didampingi oleh tim pelaksana pengabdian. Peserta kegiatan diberikan peralatan dan bahan untuk pembuatan pupuk organik cair. Secara umum peserta tidak mengalami kesulitan dalam pembuatan pupuk organik cair. Hasil pembuatan pupuk organik cair diharapkan dapat diterapkan oleh masyarakat/petani pada tanaman kelapa sawit.

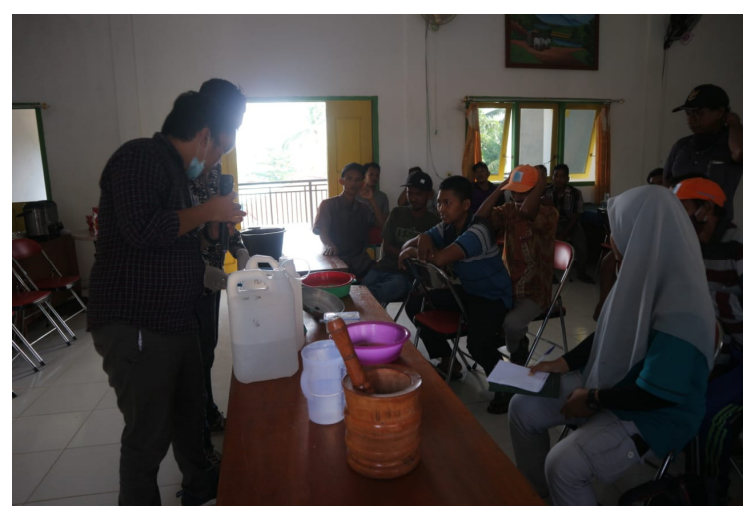

Gambar 7. Kegiatan pelatihan pembuatan pupuk organik cair

\section{KESIMPULAN}

Kegiatan pelatihan diikuti oleh masyarakat antusias dan masyarakat berperan aktif selama kegiatan berlangsung. Dengan adanya program kegiatan pengabdian masyarakat ini dapat meningkatkan keterampilan kepada masyarakat.

\section{UCAPAN TERIMAKASIH}

Terima kasih kepada LPPM Universitas Jambi atas dana PNBP Tahun 2019. 


\section{REFERENSI}

[1] Badan Pusat Statistik Provini Jambi 2014. Perkembangan Provinsi Jambi

[2] Badan Pusat Statistik Jakarta Pusat, 2016. Statistik Indonesia Tahun 2016. Jakarta Pusat: Badan Pusat Statistik

[3] Direktorat Jendral Perkebunan. 2015. Statistik Perkebunan Kelapa Sawit Indonesia Tahun 2014 - 2016. Direktorat Jendral Perkebunan, Departemen Pertanian. Jakarta.

[4] Kasmawan, I.G.A. et. al. 2018. Pembuatan Pupuk Organik Cair Menggunakan Teknologi Komposting Sederhana. Vol. 17 No 2.

[5] Khaswarina, S., 2001. Keragaman Bibit Kelapa Sawit Terhadap Pemberian Berbagai Kombinasi Pupuk di Pembibitan Utama. Jurnal Natur Indonesia. Fakultas Pertanian Universitas Sumatera Utara.

[6] Larasati Dena Mardhika, Sudradjat.2015
Respons Pertumbuhan Tanaman Kelapa Sawit (Elaeis guineensis) Belum Menghasilkan Umur Dua Tahun terhadap Pemupukan Kalsium. Bul. Agrohorti 3(1): 110-118.

[7] Palupi Nurul Puspita. 2015. Ragam Laruan Mikroorganisme Lokal Sebagai Dekomposter Rumput Gajah (Pennisetum purpureum). 40(2):123-128

[8] Purwasasmita, M. 2009. Mikroorganisme Lokal Sebagai Pemicu Siklus Kehidupan Dalam Bioreaktor Tanaman. Seminar Nasional Teknik Kimia Indonesia, 19 - 20 Oktober 2010.

Raras, N., Hadid, A., Latarang, B. 2018. Pengaruh Mikroorganisme Lokal BuahBuahan terhadap Pertumbuhan dan Hasil Tanaman Selada. E-J-Agrotekbis. 6(1), 127-135. 